\title{
Pendekatan Bermain dalam Pembelajaran Passing Atas pada Permainan Bolavoli
}

\author{
Sumbara Hambali ${ }^{1}$ \\ ${ }^{1}$ Prodi Pendidikan Jasmani Kesehatan dan Rekreasi STKIP Pasundan
}

\section{Info Artikel}

SejarahArtikel:

Diterima September 2018

Disetujui September 2018

Dipublikasikan Oktober 2018

\section{Keywords:}

Hasil Belajar, Passing atas, Pendekatan Bermain

\begin{abstract}
Abstrak
Penelitian ini bertujuan untuk meningkatkan hasil belajar passing atas pada permainan bolavoli dengan menggunakan pendekatan bermain. Subjek penelitian adalah seluruh siswa kelas V SDN Sukasirna berjumlah 24 orang. Metode penelitian menggunakan action research dengan desain Kemmis dan Taggart. Hasil penelitian yang diperoleh pada pra siklus rata-rata nilai siswa sebesar 65,35 dengan siswa yang belum tuntas sebanyak 58,3\%, sedangkan yang sudah tuntas sebanyak $41,7 \%$. Pada siklus I rata-rata nilai siswa meningkat menjadi 69,55 dengan siswa yang belum tuntas sebanyak $29,1 \%$, sedangkan yang sudah tuntas sebanyak 70,9\%. Dan pada siklus II rata-rata nilai siswa meningkat menjadi 76,27 dengan siswa yang belum tuntas sebanyak $16,7 \%$, sedangkan yang sudah tuntas sebanyak $83,3 \%$. Berdasarkan hasil tersebut dapat disimpulkan bahwa dengan menggunakan pendekatan bermain hasil belajar passing atas pada permainan bolavoli meningkat. Dengan begitu guru pendidikan jasmani dapat menggunakan pendekatan bermain dalam proses mengajarnya.
\end{abstract}




\section{PENDAHULUAN}

Pendekatan bermain merupakan salah satu upaya yang dapat dilakukan oleh para guru penjas agar proses pembelajaran penjas dapat mencerminkan DAP (Developmentally Appropriate Practice), praktek sesuai dengan tahap pengembangan yang artinya bahwa tugas ajar yang disampaikan harus memperhatikan perubahan kemampuan atau kondisi anak dan dapat membantu mendorong perubahan tersebut. Tidak sedikit guru penjas yang terjebak dalam ketergantungan penyajian materi pembelajaran kepada hal-hal yang sifatnya prinsip dan standar serta harus sesuai dengan kurikulum yang sudah ditentukan. Sehingga tidak sedikit pula guru penjas dilanda kebosanan, yang selanjutnya kondisi ini berdampak pada pembentukan dan pengembangan siswa.

Pelaksanaan pendekatan bermain merupakan salah satu alternatif atau solusi dalam menciptakan suasana belajar yang lebih efektif, dan modifikasi pendekatan bermain merupakan implementasi yang sangat berintegrasi dengan aspek pendidikan lainnya. Lutan dan Suherman (2008:69) mengatakan pengertian dan makna pendekatan bermain dalam pendidikan jasmani adalah pendekatan bermain dan peralatan, guru dapat mengurangi atau menambah tingkat kompleksitas dan kesulitan tugas ajar dengan cara memodifikasi yang digunakan untuk melakukan skill itu, misalnya: berat-ringannya, besarkecilnya, tinggi-rendahnya, panjang-pendeknya pendekatan bermain dan peralatan yang digunakan.

Tedjasaputra (2010:20) Melalui bermain pula anak memahami kaitan antara dirinya dan lingkungan sosialnya, belajar bergaul dan memahami aturan ataupun tata cara pergaulan.
Selain itu, kegiatan bermain berkaitan erat dengan perkembangan kognitif anak.

Penerapan pendekatan bermain ini dikarenakan penulis sadar betul dengan karakteristik siswa usia Sekolah Dasar yang masih dalam tahap kanak-kanak. Faktor seperti kejiwaan, yaitu keberanian, dan kepercayaan diri untuk melakukan gerakan yang baru dan dianggap sulit menurut dirinya, ini perlu dicarikan solusinya. Berbagai cara dalam pelaksanaan pembelajaran harus dikemas menjadi situasi permainan yang menyenangkan, serta peraturan permainan yang disederhanakan atau dimodifikasi harus diterapkan, sehingga para siswa akan merasa senang dalam menjalankan proses belajarnya.

Hal ini sesuai dengan ciri-ciri atau karakteristik usia sekolah dasar terutama kelas $\mathrm{V}$ yang diungkapkan oleh Husdarta \& Sugiarto (2008:32) adalah sebagai berikut :

a. Senang melakukan aktivitas yang aktif.

b. Meningkatnya perbuatan untuk melakukan olahraga kompetitif.

c. Meningkatnya minat terhadap permainan yang terorganisir.

d. Rasa kebanggaan atas keterampilan yang dikuasainya.

e. Selalu berusaha menarik perhatian orang dewasa.

f. Mempercayai orang dewasa.

g. Memperoleh kepuasan yang besar bila mencapai sesuatu, dan kecewa bila mendapatkan kegagalan.

Dengan berbagai aktivitas yang sesuai dengan karakteristik anak tersebut, diharapkan pertumbuhan dan perkembangannya seperti kecerdasan dan bakatnya akan cepat muncul dalam dirinya, sehingga keberhasilan dalam belajarnya akan cepat tercapai. Karena Tangkudung (2012:22) mengatakan kecerdasan dan bakat merupakan salah satu faktor penting 
yang turut menentukan keberhasilan atau kegagalan seseorang dalam mengikuti sesuatu kegiatan belajar atau pengalaman belajar tertentu.

Salah satu pelajaran dari pendidikan jasmani adalah permainan bolavoli. Permainan bola voli sebagai berikut merupakan olahraga ini dapat dimainkan berapapun jumlahnya, dari yang jumlahnya dua orang, yang sangat terkenal dalam bola voli pantai, sampai enam orang, jumlah pemain yang biasa digunakan dalam pertandingan antar perguruan tinggi, antar akademi, pemula, dan pertandingan antar klub Barbara L. Viera dan Bonnie Jill Fergusson (2013) .

Ada beberapa teknik dasar yang harus diberikan kepada peserta didik. Barth dan Heuchert (2009) mengatakan tindakan yang paling penting dan harus dikuasai dalam permainan bola voli adalah diantaranya : (a) Receiving, (b) Passing, (c) Attacking, (d) Blocking, (e) Back Row Defense, (f) Serving. Dari pengertian tersebut dapat diketahui salah satu teknik dasarnya ada passing. Salah satu materi yang diberikan dalam pembelajaran bolavoli adalah teknik dasar passing atas. Namun terkadang, dalam melakukan gerakannya siswa merasa enggan dan takut melakukannya, sehingga pelaksanaanya kurang maksimal. Oleh karena itu, salah satu pendekatan pembelajarannya adalah dengan bermain dan modifikasi alat.

Diharapkan dengan adanya modifikasi pendekatan bermain dan media pembelajaran dapat memotivasi siswa agar lebih aktif bergerak, serta dapat mengatasi kompleksitas pembelajaran pola gerak dasar siswa sekolah dasar. Karena permainan merupakan kegiatan yang dirancang dengan aturan sendiri, sehingga dapat memberikan stimulus yang mendekati ken- yataan sehari-hari. Dari sinilah dapat dilihat respon yang muncul dan kemudian digunakan sebagai alat evaluasi diri(Lengkong dan Dwi, 2008:39). Berdasarkan uraian tersebut, maka yang menjadi tujuan dalam penelitian ini adalah untuk meningkatkan hasil belajar passing atas pada siswa SDN Sukasirna dengan model pendekatan bermain.

\section{METODE PENELITIAN}

Metode penelitian yang digunakan adalah metode Penelitian Tindakan Kelas (Clasroom Action Research), denga desain Kemmis dan Taggart. Setiap tindakan upaya perencanaan tujuan tersebut dirancang dalam suatu unit sebagai suatu siklus. Setiap siklus terdiri dari empat tahapan, yakni (1) perencanaan tindakan; (2) pelaksanaan tindakan; (3) observasi dan imperprestasi; (4) analisis dan refleksi untuk perencanaan siklus berikutnya. Penelitian ini terjadi selama dua siklus, dimana setiap siklus terdiri dari tiga pertemuan/tatap muka.

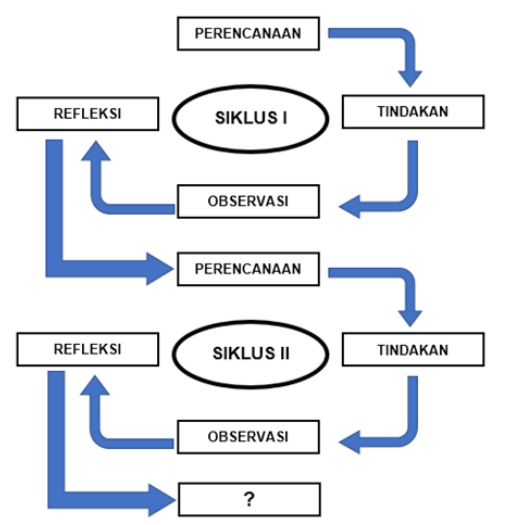

Gambar 1. Desain Penelitian Tindakan Model Kemmis dan Mc Taggart (2014)

Pelaksanaan penelitian melibatkan rekan sejawat sebagai kolaborator dan guru kelas sebagai pelaksana tindakan. Hasil akhir dari 
kegiatan penelitian tindakan adalah meningkatkan hasil belajar khususnya pembelajaran pendidikan jasmani pada materi passing atas di SD Negeri Sukasirna Semester Genap Tahun Pelajaran 2016 / 2017.

Subjek dalam penelitian ini adalah semua siswa kelas V SDN Sukasirna yang berjumlah 24 orang (laki-laki 12 orang dan Perempuan 12 orang). Instrumen yang digunakan dalam penelitian ini adalah tes hasil belajar passing atas dalam permainan bolavoli, observasi dan catatan lapangan. Kriteria keberhasilan dalam penelitian ini adalah apabila hasil belajar siswa pada setiap siklusnya mengalami peningkatan, dan secara keseluruhan siswa yang tuntas sudah ada sebanyak $80 \%$.

Analisis data dalam penelitian ini adalah deskriptif kualitatif dan kuantitatif. Data kuantitatif membandingkan data tes awal dan hasil tes setelah siklus 1 dan 2. Sedangkan kualitatif adalah refleksi dalam setiap siklusnya berdasarkan hasil observasi yang terekam dalam catatan lapangan, dokumentasi, dan observasi. Analisis data dilakukan secara deskriptif dengan membandingkan hasil pencapaian dengan indikator keberhasilan.

Data yang dikumpulkan pada setiap kegiatan observasi dari pelaksanaan siklus PTK dianalisis secara deskriptif dengan menggunakan prosentase untuk melihat kecenderungan yang terjadi dalam kegiatan pembelajaran pendidikan jasmani siswa kelas V SDN Sukasirna Semester Genap Tahun Pelajaran 2016/2017.

\section{HASIL PENELITIAN}

\section{Pra Siklus}

Hasil yang diperoleh dari pra siklus adalah Siswa kurang memiliki perhatian dan moti- vasi dalam pembelajaran passing atas dalam permainan bolavoli, karena pembelajaran masih menggunakan motode konvensional dan kurang menggunakan media pembelajaran yang bervariasi.

Saat mengikuti pembelajaran pendidikan jasmani, siswa masih menunjukkan sikap seenaknya sendiri, kurang memperhatikan penjelasan guru, kurang memperhatikan pelajaran dengan sepenuhnya, ada yang berbicara dengan teman, bahkan ada yang bermain sendiri dengan temannya. Guru masih kesulitan menemukan contoh/model pembelajaran yang baik untuk materi passing atas dalam permainan bolavoli. Seringkali contoh/demonstarsi yang disampaikan oleh guru melalui peragaan langsung, kurang dapat dicermati oleh siswa secara baik. Dan untuk hasil belajar passing atas siswa pada saat pra siklus, penulis akan sajikan dalam bentuk tabel dan diagram sebagai berikut :

Berdasarkan data diatas maka dapat dilihat bahwa sebelum diberikan tindakan mayoritas siswa belum menunjukan hasil bela-

Tabel 1 : Tes Hasil Belajar Passing Atas Pra Siklus

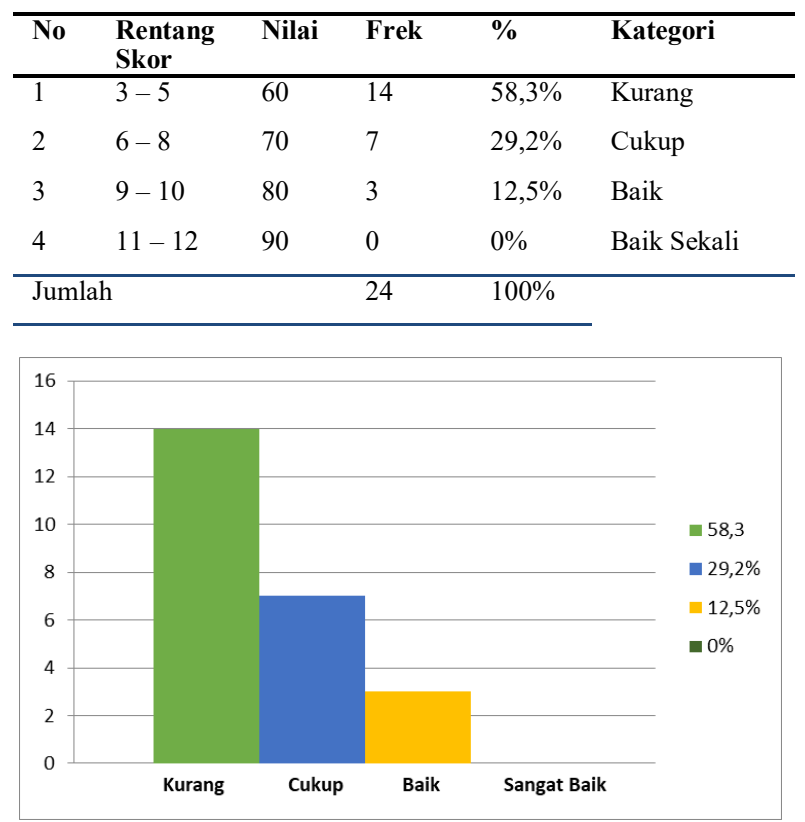

Gambar 1. Diagram Hasil Belajar Passing atas Pra Siklus 
jar cukup baik, dengan prosentase ketercapaian sebagai berikut : Kriteria Baik Sekali $=0 \%$, Baik $=12,5 \%$, Cukup $=29,2 \%$, Kurang $=$ $58,3 \%$. Berdasarkan deskripsi data tersebut dapat disimpulkan baahwa tingkat keberhasilan pembelajaran yang diperoleh masih belum memuaskan. Untuk itu peneliti menyusun sebuah tindakan untuk meningkatkan kualitas pembelajaran materi passing atas dalam permainan bolavoli pada siswa di kelas tersebut.

\section{Siklus I}

Pada dasarnya pembelajaran melalui pendekatan bermain cukup memberikan semangat kepada siswa dalam melakukan gerakan passing atas dalam permainan bolavoli, sehingga siswa lebih antusias dalam mengikuti pembelajaran, hal ini dapat diamati dari sikap yang awalnya khawatir dalam melakukan gerakan passing atas, berubah menjadi suatu hal yang menyenangkan setelah menggunakan pendekatan bermain.

Pada bagian ini penulis akan memaparkan tentang data hasil tes passing atas dalam permainan bolavoli. Berikut data hasil tes passing atas dalam permainan bolavoli yang disajikan oleh penulis melalui tabel dan diagram dibawah ini :

Tabel 1 : Tes Hasil Belajar Passing Atas Siklus I

\begin{tabular}{llllll}
\hline No & $\begin{array}{l}\text { Rentang } \\
\text { Skor }\end{array}$ & Nilai & Fre & Porsentase & Kategori \\
\hline 1 & $3-5$ & 60 & 7 & $29,2 \%$ & Kurang \\
2 & $6-8$ & 70 & 9 & $37,5 \%$ & Cukup \\
3 & $9-10$ & 80 & 6 & $25 \%$ & Baik \\
4 & $11-12$ & 90 & 2 & $8,3 \%$ & Baik Sekali \\
\hline \multicolumn{2}{l}{ Jumlah } & & 24 & $100 \%$ & \\
\hline
\end{tabular}

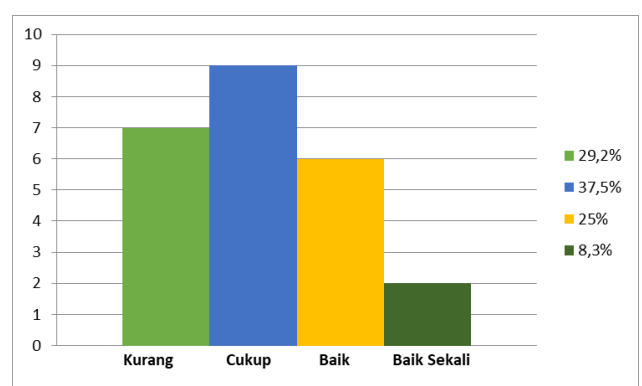

Gambar 1. Diagram Hasil Belajar Passing Atas Siklus I

Berdasarkan data tersebut diatas dapat dikemukakan hal-hal sebagai berikut: siswa yang berada pada kategori kurang dengan nilai 60 sebanyak 7 orang $(29,2 \%)$, siswa yang berada pada kategori cukup dengan nilai 70 sebanyak 9 orang $(37,5 \%)$, siswa yang berada pada kategori baik dengan 80 sebanyak 6 orang (25\%), dan siswa yang berada pada kategori baik sekali dengan nilai 90 ada 2 orang $(8,3 \%)$.

\section{Siklus II}

Berdasarkan hasil observasi yang telah dilakukan oleh peneliti dan kolabolator maka dapat disimpulkan pada siklus ke II siswa semakin antusias melakukan pembelajaran passing atas, tampak tidak ada ada kejenuhan dari siswa. Pada saat pembelajaran siswa nampak senang dengan metode pembelajaran yang diterapkan oleh guru. Pembelajaran passing atas melalui pendekatan bermain, siswa sudah mulai bisa menikmati pembelajaran, hal tersebut dikarenakan guru meancang suasana kelas menjadi suasana kompetisi. Hal ini terlihat dari sikap siswa yang cenderung selalu ingin mencoba lagi untuk melakukan gerakan passing atas.

Pada bagian ini, peneliti akan memaparkan data tes hasil passing atas dalam permainan bolavoli. Data tersebut peneliti akan sajikan dalam bentuk tabel dan diagram sebagai berikut : 
Tabel 3 : Tes Hasil Belajar Passing Atas Pra Siklus III

\begin{tabular}{llllll}
\hline No & $\begin{array}{l}\text { Rentang } \\
\text { Skor }\end{array}$ & Nilai & Frek & \% & Kategori \\
\hline 1 & $3-5$ & 60 & 4 & $16,6 \%$ & Kurang \\
2 & $6-8$ & 70 & 6 & $25 \%$ & Cukup \\
3 & $9-10$ & 80 & 11 & $45,8 \%$ & Baik \\
4 & $11-12$ & 90 & 3 & $12,5 \%$ & Baik Sekali \\
\hline \multicolumn{2}{ll}{ Jumlah } & & 24 & $100 \%$ & \\
\hline
\end{tabular}

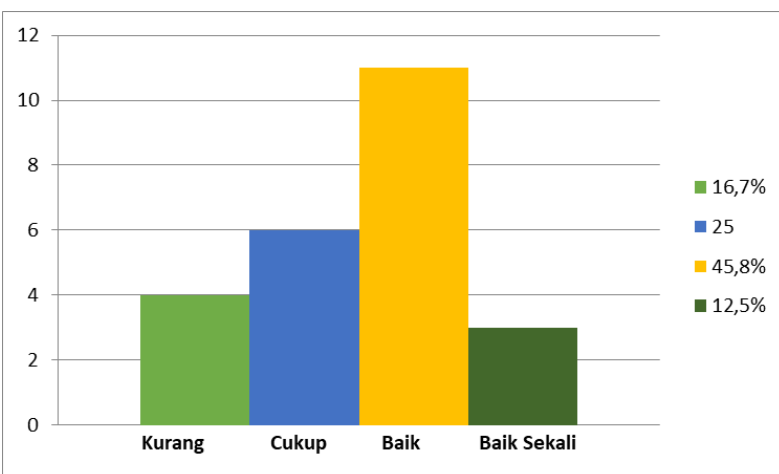

Gambar 1. Diagram Hasil Belajar Passing Atas Siklus I I

Berdasarkan data tersebut diatas dapat dikemukakan hal-hal sebagai berikut: siswa yang berada pada kategori kurang dengan nilai 60 sebanyak 4 orang $(16,7 \%)$, siswa yang berada pada kategori cukup dengan nilai 70 sebanyak 6 orang $(25 \%)$, siswa yang berada pada kategori baik dengan 80 sebanyak 11 orang $(45,8 \%)$, dan siswa yang berada pada kategori baik sekali dengan nilai 90 ada 3 orang $(12,5 \%)$.

Dengan begitu, maka dapat dikatakan bahwa pada siklus II penelitian telah mencapai target yang diinginkan yaitu secara keseluruhan $80 \%$ ketuntasan, dan pada siklus II ini siswa yang telah tuntas sebanyak $83,3 \%$, hal tersebut menunjukan penelitian ini sudah melebihi target yang diinginkan. Oleh karena itulah, peneliti berkeputusan tidak melanjutkan penelitian pada siklus berikutnya.
Perbandingan hasil belajar passing atas dalam permainan bolavoli terjadi peningkatan pada setiap siklusnya. Hal tersebut dapat dibuktikan dengan adanya pengurangan persentase siswa yang belum tuntas dalam setiap siklusnya. Pada pra siklus terdapat 14 orang $(41,7 \%)$ yang belum tuntas, pada siklus I terdapat 7 orang $(29,2 \%)$ yang belum tuntas, dan pada siklus II mengalami penurunan lagi menjadi hanya 4 orang yang belum tuntas (16,7\%). Ini menandakan bahwa pada setiap siklusnya, hasil belajar siswa mengalami peningkatan. Agar lebih jelasnya, berikut diagram perbandingan hasil belajar siswa di setiap siklusnya:

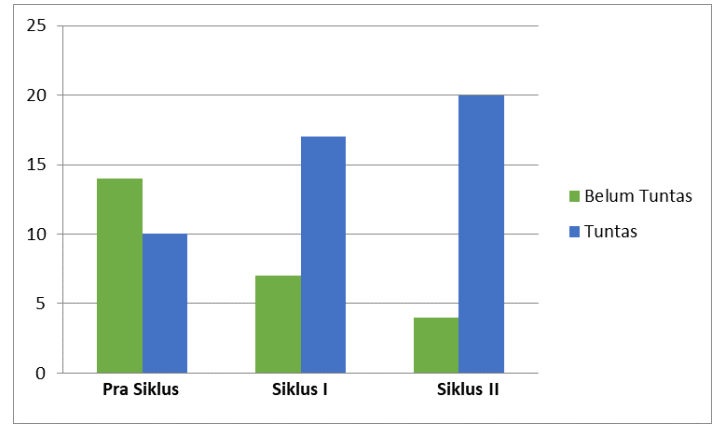

Gambar 1. Diagram Hasil Belajar Passing Atas Siklus I I

\section{KESIMPULAN}

Berdasarkan hasil penelitian yang telah dilakukan, maka peneliti dapat menyimpulkan bahwa pendekatan bermain pada permaian bolavoli dapat meningkatkan hasil belajar passing atas pada siswa SDN Sukasirna Semester Genap Tahun Pelajaran 2016 / 2017. Penerapan Pendekatan bermain menggunakan alat yang sederhana dalam pembelajaran passing atas dalam permainan bolavoli merupakan salah satu alternatif dalam memecahkan beberapa masalah yang dihadapi guru dalam upaya mengaktifkan 
siswa dalam belajar. Oleh karena itu, guru harus mampu menciptakan kelas yang konduksif agar hubungan interaktif siswa dengan guru, siswa dengan siswa dapat terwujud dengan baik, sehingga suasana kelas menjadi aktif dan menarik.

\section{DAFTAR PUSTAKA}

Lutan, Rusli dan Suherman, Adang. (2008). Perencanaan Pembelajaran Penjaskes. Jakarta: Depniknas.

Husdarta, J.S dan S.G Bambang. (2008). Pertumbuhan dan Perkembangan Peserta Didik. Cimahi: STKIP Pasundan, 2008.

Kemmis, Stephan, McTaggart, Robin, dan Nixon, Rhonda. (2014). The Action Research Planner. Doing Critical Participatory Action Research. Springer.

Tangkudung, J dan Wahyuningtyas, P. (2012). Kepelatihan Olahraga Edisi II. Jakarta: Cerdas Jaya, 2012.

Tedjasaputra, S Mayke. (2010). Bermain, Main dan Permainan Untuk Usia Dini. Jakarta: Grasindo.

Lengkong, Putra dan Dwi, Bintang. (2008). Games Seru Fun Outbond Yogyakarta: Galang Press.

Barbara L. Viera dan Bonnie Jill Fergusson. (2013). Bola Voli Tingkat Pemula terjemahan Monti. Jakarta: PT. Raja Grafindo Persada.

Katrin Barth dan Richard Heuchert. (2009). Learning Volleyball. New York: Mayer \& Mayer Sport. 